\title{
Recycling and treatment of construction sludge
}

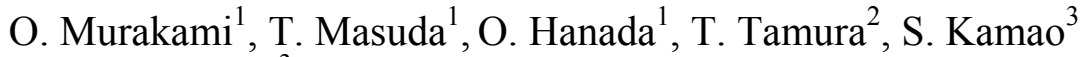 \\ \& M. Takezawa ${ }^{3}$ \\ ${ }^{1}$ MURA CAM Co. Ltd., Japan \\ ${ }^{2}$ TAMURA Co. Ltd., Architecture Office, Japan \\ ${ }^{3}$ Department of Civil Engineering, Nihon University, Japan
}

\begin{abstract}
Construction sludge consists of fine-particle mud with a high water content. It is drained in the process of excavating underground and building projects, and falls under the category of industrial waste in Japan's Waste Disposal Law. Many components of construction sludge can potentially be recycled. The government and local authorities in Japan regulate how much sludge should be recycled before it is hauled away to landfills or other sludge treatment facilities. Recently, there have been increasingly strident public calls for the regulation of natural sands to reduce resource impoverishment and promote natural conservation. Recycled natural resources including natural sands, recycled gravels, improved soils, and fluidization process soils using construction sludge were produced as the primary material. Recycled natural sands and gravels are materials contained in the construction sludge, which are then graded and washed. They are used for sand cushions and backfill material. Improved soils are recycled sands and viscous soils that have been washed and separated from construction sludge, with a chemical product added to enhance their performance. Fluidization process soils are high quality, stable materials derived from construction sludge. All of these materials meet the environmental quality standards of Japan's Environmental Agency. Recycling is processing used materials into new products to prevent waste of potentially useful materials; reduce the consumption of fresh raw materials; reduce energy usage; reduce air pollution and water pollution from landfills by reducing the need for conventional waste disposal, and lower greenhouse gas emission as compared to virgin production. Recycling is a key component of modern waste reduction and is the third facet of the "Reduce, Reuse, Recycle" waste hierarchy. It must be strived to use properly recycled resources. This study demonstrates an effective means of recycling
\end{abstract}


construction sludge and that high quality fluidization process soils can be produced using construction sludge as a primary material.

Keywords: construction sludge, recycle natural sand, improved soil, fluidization process soil, reclaimed soil.

\section{Introduction}

Recently, the Japanese government and municipalities have been pushed by the public to enact sand and gravel collection regulations to avoid exhausting resources and protect the natural environment. Some companies in Japan have developed technologies to treat and recycle construction site sludge instead of hauling it away for disposal [1]. The technology involves using a special cement to neutralize the sludge on-site and treat it to make it harmless enough to use as backfill soil. Construction sludge is mud that has a cone-index under $200 \mathrm{kN} / \mathrm{m}^{3}$ or an unconfined compressive strength under $50 \mathrm{kN} / \mathrm{m}^{2}$. It is treated as an industrial solid waste material and regulated by the waste disposal law based on its consistency, which cannot be walked upon [2]. Until now, this has meant paying huge costs for transportation and disposal. A new technology to recycle construction sludge at dam and tunnel construction sites was developed. The government or local authorities often make rules about how much sludge should be sorted before it is hauled away to landfills or other waste treatment facilities. Some hazardous materials may not be moved before the authorities have ascertained that safety guidelines and restrictions have been followed. Many elements of construction sludge can be recycled into several sizes of gravels that can be reused in construction and screened sand that can be used for ancillary construction purposes.

The Japanese Ministry of Land, Infrastructure and Transport promulgated guidelines for recycling construction sludge in 2006 [3] in order to promote recycling of construction sludge, to cut the amount hauled to final disposal sites, and to prevent improper disposal. It outlines a basic policy and concrete enforcement procedures for the disposal of construction sludge generated by construction projects. Little construction sludge is now recycled and the residual capacity of final disposal sites is dwindling. Therefore how to reduce the amount of construction sludge sent to final disposal is an urgent problem.

\section{Classification technology and recycled products}

A system to separate construction sludge into its constituents and have produced recycled products from such sludge was developed [4]. The system can separate particles in the sludge down to a diameter of $10 \mu \mathrm{m}$. The components of the method and treatment capacity are as follows: Dewatering: $1,104 \mathrm{~m}^{3} /$ day, grading and separation: $2,592 \mathrm{~m}^{3} /$ day, fluidization treatment: $471.2 \mathrm{~m}^{3} /$ day, granulated solidification: $320 \mathrm{~m}^{3} /$ day, and sun drying: $84 \mathrm{~m}^{3} /$ day. Figure 1 outlines the classification and separation system developed using the new technology. Figures 2 and 3 show working views. Part of the construction sludge is put into a pit and reclaimed, producing recycled products such as sand, gravel, 
improved soil, and fluidization process soil. The rest is placed in a sunlightdrying pit. Sludge taken from pit (A) is washed in water (C) and separated into sand, small gravel and large gravel by the first classifier (1). The sludge is repeatedly separated into its different constituents in a series of classifiers. The final products of this system are recycled natural sand, improved soil and fluidization process soil.

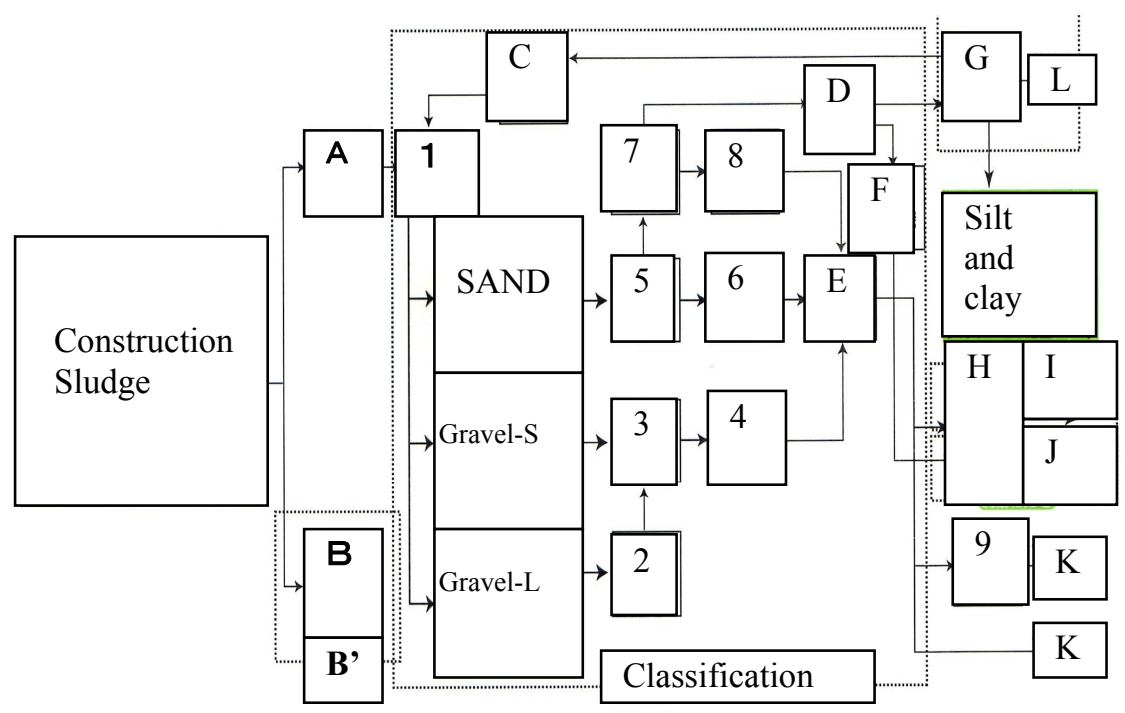

Figure 1: $\quad$ Classifier system. A: supply pit, B: sunlight drying pit, B': sunlight dry, C: washing water, D: muddy water, E: sand, F: weighing machine, G: presses, H: mixer, I: improved soil, J: fluidization process soil, K: sand, L: discharge, 1: first classifier, 2: second classifier, 3: third classifier, 4: fourth classifier, 5: fifth classifier, 6: sixth classifier, 7: seventh classifier, 8: eighth classifier, 9: ninth classifier.

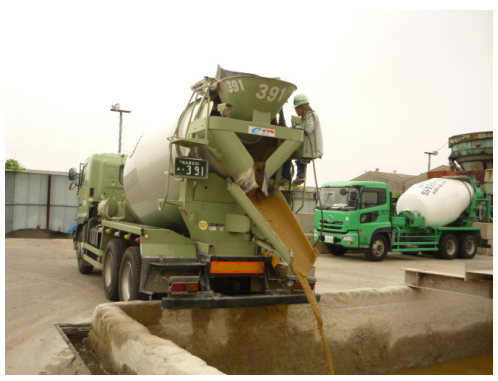

Figure 2: $\quad$ Placing sludge in pit

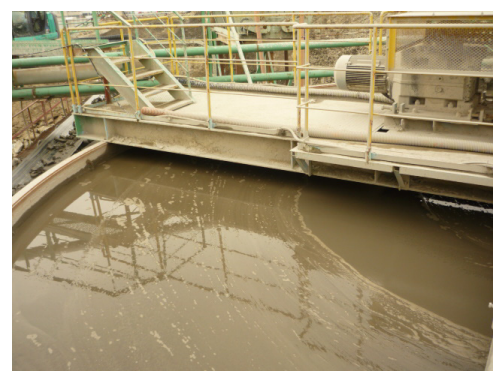

Figure 3: Washing sludge in water. 


\section{Recycled natural sand}

Recycled natural sand is produced by classifying and washing construction sludge. Its characteristics make it suitable for use in sand cushions and for backfill. The safety was confirmed monthly by using the standard soil dissolution test for soil pollution $\left(46^{\text {th }}\right.$ article of the Ministry of the Environment's bulletin) [5]. The quality of the recycled natural sand is tightly and consistently controlled. Particle size (sieve analysis test) was monitored and washing and Alkali-aggregate reaction testing were performed. The recycled natural sand is certified by the Aichi Prefecture Recycled Materials (nicknamed AIKURU) system, which has been evaluating recycled products in Aichi Prefecture, Japan since 2002 [6]. This system was created to promote the use of many recycled materials in public works and has become a moving force behind recycling. Figure 4 outlines the operation of the AIKURU system: (1) AIKURU create standards for confirming materials' safety and usability in public works, (2) it certifies and registers the materials satisfying its standards as AIKURU MATERIALS, (3) the registered materials are used in public works. Figure 5 shows the recycled natural sand produced by the classifier system.

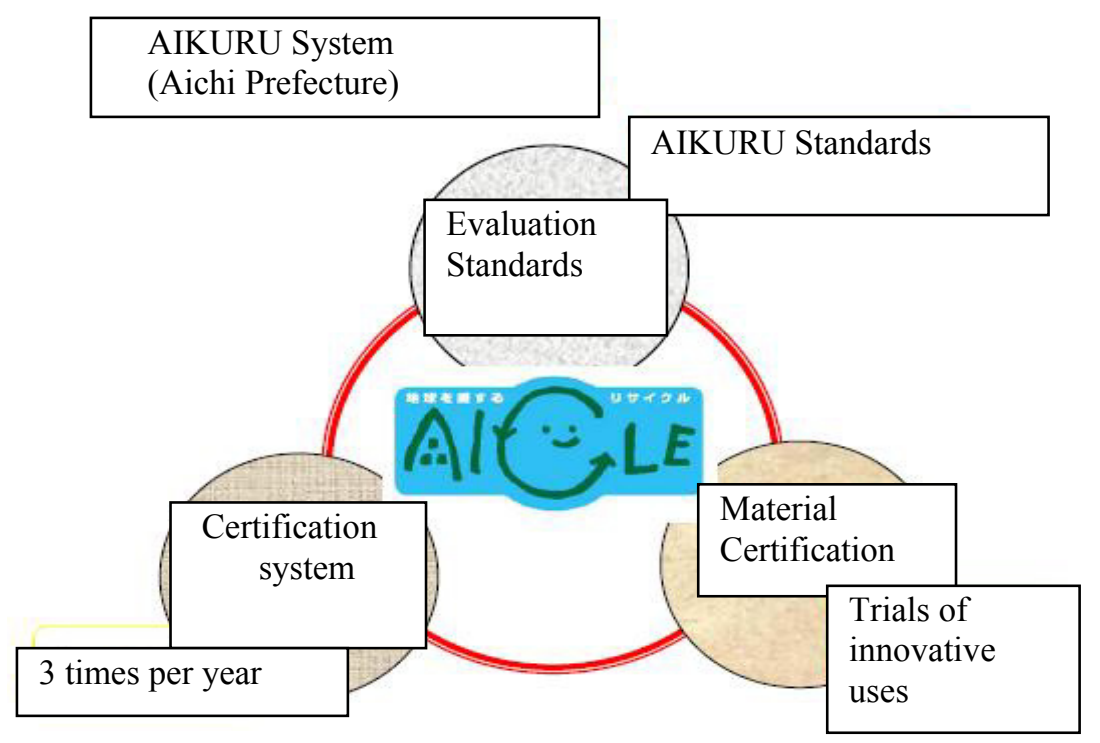

Figure 4: AIKURU system. 


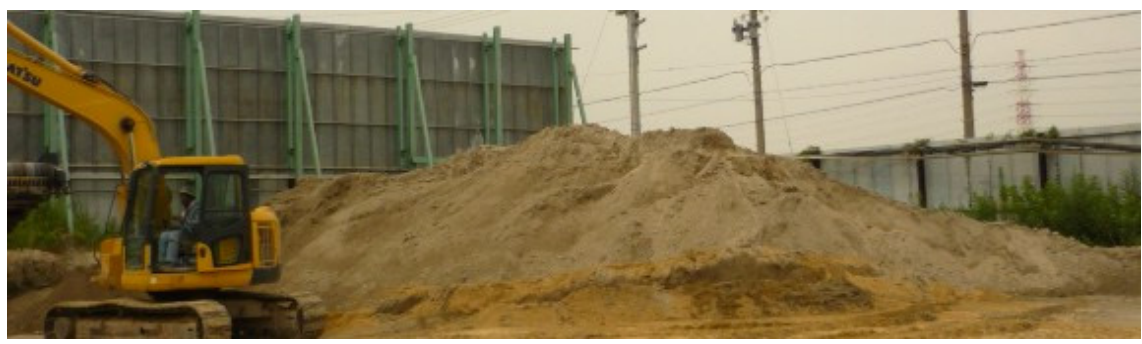

Figure 5: $\quad$ Recycled natural sand.

\section{Fluidization process soil}

Fluidization process soil produced from construction sludge is a new backfilling material that does not require compaction by mechanical compactors. It takes less time to place fluidization process soil than conventional soils, it hardens quickly, and is very strong because of the variation of particle sizes available in the construction sludge from which it is made. A high quality, stable fluidization process soil by compounding mud, sand, silt and clay was produced. Type B Portland blast furnace cement (JIS R 5211 standard) is used as the solidification chemical. The specification for the cement is shown in Table 1 [7].

Table 1: $\quad$ Type B Portland blast furnace cement specifications.

\begin{tabular}{|c|c|c|c|c|c|}
\hline Quality & Unit & JIS & Aver. & SD & Max (Min) \\
\hline Density & $\mathrm{g} / \mathrm{cm}^{3}$ & & 3.04 & & \\
\hline Specific surface area & $\mathrm{cm}^{2} / \mathrm{g}$ & $>3000$ & 3730 & 80 & \\
\hline $\begin{array}{c}\text { Condensation water } \\
\text { volume }\end{array}$ & $\%$ & & 29.4 & & \\
\hline Condensation start time & h-min & $>60 \mathrm{~min}$ & $2-46$ & & $(2.25)$ \\
\hline Condensation end time & h-min & $<10 \mathrm{~h}$ & $4-05$ & & $4-55$ \\
\hline $\begin{array}{c}\text { Stability } \\
\begin{array}{c}\text { Compressive strength } \\
(3 \mathrm{~d})\end{array}\end{array}$ & Pat Method & Good & Good & & \\
\hline $\begin{array}{c}\text { Compressive strength } \\
(7 \mathrm{~d})\end{array}$ & $\mathrm{N} / \mathrm{mm}^{2}$ & $>10.0$ & 22.3 & 1.26 & \\
\hline $\begin{array}{c}\text { Compressive strength } \\
(28 \mathrm{~d})\end{array}$ & $\mathrm{N} / \mathrm{mm}^{2}$ & $>42.5$ & 62.8 & 1.94 & \\
\hline $\mathrm{MgO}^{\mathrm{SO}}$ & & $<6.0$ & 3.45 & & 3.67 \\
\hline $\mathrm{Ignition} \mathrm{loss}_{\mathrm{Cl}}^{-}$ & & $<4.0$ & 2.09 & & 2.16 \\
\hline & & $<5.0$ & 1.57 & & 1.96 \\
\hline
\end{tabular}

The following quality control tests were carried out to confirm the quality of the fluidization process soil: (1) Bleeding test, (2) Test of unconfined compression strength, (3) Soil density test, and (4) Flow value test. Typical standard mix proportions are as follows: (1) solidification chemical, 
$50-500 \mathrm{~kg} / \mathrm{m}^{3}$, (2) slurry, 280-600 1/ $\mathrm{m}^{3}$, (3) recycled sand, $300-1600 \mathrm{~kg} / \mathrm{m}^{3}$ and silt, $200-1400 \mathrm{~kg} / \mathrm{m}^{3}$. The soil's quality parameters are as follows: (1) Unconfined compressive strength: $0.3-4.0 \mathrm{~N} / \mathrm{mm}^{2}$, (2) Soil density: $1.3-$ $1.9 \mathrm{~g} / \mathrm{cm}^{3}$, (3) Bleeding rate: under $3 \%$ (in highly variable filling situations: under 1\%), (4) Flow value: above $110 \mathrm{~mm}$. Typical applications are backfilling of vertical shafts for shield works, underground structures, and retaining walls. The new geo-cement by using a stabilizing agent and long-term strength retainer was made. The fluidity and strength of this new geo-cement is measured on liquefied and stabilized soil. A comparison is made with a locally available stabilizer. Cylindrical samples taken for comparison were $5 \mathrm{~cm}$ in diameter, $10 \mathrm{~cm}$ long and varied from 1 to 84 days old. Their respective strengths and deformations were measured. The fluidity of the stabilized soil under simulated site conditions was also measured. The experimental results showed that the strength of the liquefied, stabilized soil containing geo-cement rose quickly in the first days but no significant incremental improvement was found later, confirming that this new type of geocement has a restraining effect on long term strength. Standard values for the characteristics of fluidization process soil are shown in Tables 2(a) to (d), where flow value is above $110 \mathrm{~mm}$, bleeding rate is below $1 \%$ to $3 \%$, and specific gravity is $1.30 \mathrm{t} / \mathrm{m}^{3}$ to $1.90 \mathrm{t} / \mathrm{m}^{3}$. The component materials are Type B Portland blast furnace cement, recycled natural sand and silt. The temperature during water curing was $20^{\circ} \mathrm{C}$.

Table 2: $\quad$ (a) Standard values (average temperature $15-25^{\circ} \mathrm{C}$ ).

\begin{tabular}{|c|c|c|c|c|c|c|c|}
\hline & BB50 & BB70 & BB90 & BB100 & BB110 & BB120 & BB130 \\
\hline$\sigma 3$ & 0.03 & 0.08 & 0.13 & 0.16 & 0.20 & 0.23 & 0.26 \\
\hline$\sigma 7$ & 0.08 & 0.20 & 0.32 & 0.38 & 0.43 & 0.48 & 0.55 \\
\hline$\sigma 28$ & 0.20 & 0.50 & 0.70 & 0.80 & 0.90 & 1.00 & 1.20 \\
\hline
\end{tabular}

Table 2: $\quad$ (b) Standard values (average temperature above $25^{\circ} \mathrm{C}$ ).

\begin{tabular}{|c|c|c|c|c|c|c|c|}
\hline & BB50 & BB70 & BB90 & BB100 & BB110 & BB120 & BB130 \\
\hline$\sigma 3$ & 0.07 & 0.16 & 0.25 & 0.30 & 0.34 & 0.38 & 0.45 \\
\hline$\sigma 7$ & 0.15 & 0.32 & 0.50 & 0.60 & 0.68 & 0.75 & 0.90 \\
\hline$\sigma 28$ & 0.30 & 0.65 & 1.00 & 1.20 & 1.35 & 1.50 & 1.80 \\
\hline
\end{tabular}

Table 2: $\quad$ (c) Standard values (average temperature $8-15^{\circ} \mathrm{C}$ ).

\begin{tabular}{|c|c|c|c|c|c|c|c|}
\hline & BB50 & BB70 & BB90 & BB100 & BB110 & BB120 & BB130 \\
\hline$\sigma 3$ & 0.02 & 0.07 & 0.10 & 0.13 & 0.15 & 0.18 & 0.20 \\
\hline$\sigma 7$ & 0.06 & 0.18 & 0.27 & 0.30 & 0.34 & 0.38 & 0.45 \\
\hline$\sigma 28$ & 0.15 & 0.43 & 0.58 & 0.65 & 0.72 & 0.80 & 1.00 \\
\hline
\end{tabular}

The quality of fluidization process soil is regulated depending on its application as shown in Table 3. Figures 6 to 9 show pouring of fluidization process soil. 
Table 2: $\quad$ (d) Standard values (average temperature under $8^{\circ} \mathrm{C}$ ).

\begin{tabular}{|c|c|c|c|c|c|c|c|}
\hline & BB50 & BB70 & BB90 & BB100 & BB110 & BB120 & BB130 \\
\hline$\sigma 3$ & 0.02 & 0.06 & 0.08 & 0.10 & 0.12 & 0.13 & 0.15 \\
\hline$\sigma 7$ & 0.05 & 0.14 & 0.22 & 0.26 & 0.29 & 0.32 & 0.35 \\
\hline$\sigma 28$ & 0.12 & 0.35 & 0.50 & 0.57 & 0.63 & 0.70 & 0.82 \\
\hline
\end{tabular}

$\sigma 3$ : average compressive strength $\left(\mathrm{N} / \mathrm{mm}^{2}\right)$ at 3 days, $\sigma 7$ : average compressive strength $\left(\mathrm{N} / \mathrm{mm}^{2}\right)$ at 7 days, 628: average compressive strength $\left(\mathrm{N} / \mathrm{mm}^{2}\right)$ at 28 days, BB50: unit weight of cement $50 \mathrm{~kg} / \mathrm{m}^{3}$, BB70: unit weight of cement $70 \mathrm{~kg} / \mathrm{m}^{3}$, BB90: unit weight of cement $90 \mathrm{~kg} / \mathrm{m}^{3}$, BB100: unit weight of cement $100 \mathrm{~kg} / \mathrm{m}^{3}$, BB110: unit weight of cement $110 \mathrm{~kg} / \mathrm{m}^{3}, \mathrm{BB} 12$ : unit weight of cement $120 \mathrm{~kg} / \mathrm{m}^{3}$, BB130: unit weight of cement $130 \mathrm{~kg} / \mathrm{m}^{3}$

Table 3: $\quad$ Fluidization process soil quality parameters.

\begin{tabular}{|c|c|c|}
\hline Use & Applications & Test parameters \\
\hline $\begin{array}{l}\text { Backfilling } \\
\text { of } \\
\text { underground } \\
\text { structures }\end{array}$ & $\begin{array}{l}\text { Precursor for } \\
\text { common ducts, } \\
\text { Underground } \\
\text { parking, } \\
\text { Box culverts, } \\
\text { Open tunnels etc. }\end{array}$ & $\begin{array}{c}\text { Max diameter: under } 40 \mathrm{~mm} \\
\text { Uniaxial compressive strength: above } 300 \mathrm{kN} / \mathrm{m}^{2} \\
\text { Flow value: above } 110 \mathrm{~mm} \\
\text { Bleeding rate: under } 1 \% \\
\text { Density of soil: above } 1.5 \mathrm{~g} / \mathrm{cm}^{3}\end{array}$ \\
\hline $\begin{array}{c}\text { Backfilling } \\
\text { of structures } \\
\text { (Civil } \\
\text { Engineering) }\end{array}$ & $\begin{array}{l}\text { Retaining walls } \\
\text { Abutments }\end{array}$ & $\begin{array}{c}\text { Max diameter: under } 40 \mathrm{~mm} \\
\text { Uniaxial compressive strength: above } 100 \mathrm{kN} / \mathrm{m}^{2} \\
\text { Flow value: above } 110 \mathrm{~mm} \\
\text { Bleeding rate: under } 1 \% \\
\text { Density of soil: } 1.6 \mathrm{~g} / \mathrm{cm}^{3} \\
\end{array}$ \\
\hline $\begin{array}{c}\text { Filling } \\
\text { underground } \\
\text { spaces }\end{array}$ & $\begin{array}{l}\text { Filling of tunnels } \\
\text { or disused mines }\end{array}$ & $\begin{array}{c}\text { Max diameter: under } 40 \mathrm{~mm} \\
\text { Uniaxial compressive strength: above } 300 \mathrm{kN} / \mathrm{m}^{2} \\
\text { Flow value: above } 200 \mathrm{~mm} \\
\text { Bleeding rate: under } 3 \% \\
\text { Density of soil: } 1.4 \mathrm{~g} / \mathrm{cm}^{3} \\
\end{array}$ \\
\hline $\begin{array}{l}\text { Filling small } \\
\text { cavities }\end{array}$ & $\begin{array}{l}\text { Cavities under } \\
\text { roads or behind } \\
\text { structures, interior } \\
\text { of retired pipes, } \\
\text { etc. }\end{array}$ & $\begin{array}{c}\text { Max diameter: under } 40 \mathrm{~mm} \\
\text { Uniaxial compressive strength: above } 300 \mathrm{kN} / \mathrm{m}^{2} \\
\text { Flow value: above } 200 \mathrm{~mm} \\
\text { Bleeding rate: under } 3 \% \\
\text { Density of soil: } 1.4 \mathrm{~g} / \mathrm{cm}^{3} \\
\end{array}$ \\
\hline $\begin{array}{l}\text { Backfilling } \\
\text { of } \\
\text { underground } \\
\text { pipes }\end{array}$ & $\begin{array}{c}\text { Gas pipes, water } \\
\text { and sewer pipes, } \\
\text { etc. }\end{array}$ & $\begin{array}{c}\text { Max diameter: under } 13 \mathrm{~mm} \\
\text { Uniaxial compressive strength: } 200-600 \mathrm{kN} / \mathrm{m}^{2} \\
\text { (28days) } \\
\text { Flow value: above } 140 \mathrm{~mm} \\
\text { Bleeding rate under } 3 \% \\
\text { Density of soil: } 1.4 \mathrm{~g} / \mathrm{cm}^{3}\end{array}$ \\
\hline $\begin{array}{l}\text { Protection } \\
\text { under pipes }\end{array}$ & $\begin{array}{c}\text { Gas pipes, water } \\
\text { and sewer pipes, } \\
\text { etc. }\end{array}$ & $\begin{array}{c}\text { Max diameter: under } 40 \mathrm{~mm} \\
\text { Uniaxial compressive strength: above } 300 \mathrm{kN} / \mathrm{m}^{2} \\
\text { Flow value: above } 110 \mathrm{~mm} \\
\text { Bleeding rate: under } 1 \% \\
\text { Density of soil: } 1.4 \mathrm{~g} / \mathrm{cm}^{3}\end{array}$ \\
\hline $\begin{array}{l}\text { Backfilling } \\
\text { around } \\
\text { foundations }\end{array}$ & $\begin{array}{l}\text { Around pile } \\
\text { foundations, } \\
\text { cavities under } \\
\text { structures, etc. }\end{array}$ & $\begin{array}{c}\text { Max diameter: under } 40 \mathrm{~mm} \\
\text { Uniaxial compressive strength: above } 100 \mathrm{kN} / \mathrm{m}^{2} \\
\text { Flow value: above } 110 \mathrm{~mm} \\
\text { Bleeding rate: under } 1 \% \\
\text { Density of soil: } 1.6 \mathrm{~g} / \mathrm{cm}^{3}\end{array}$ \\
\hline
\end{tabular}




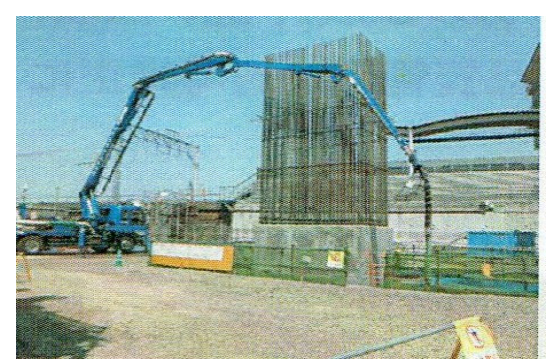

Figure 6: Pouring fluidization process soil using a pump car.

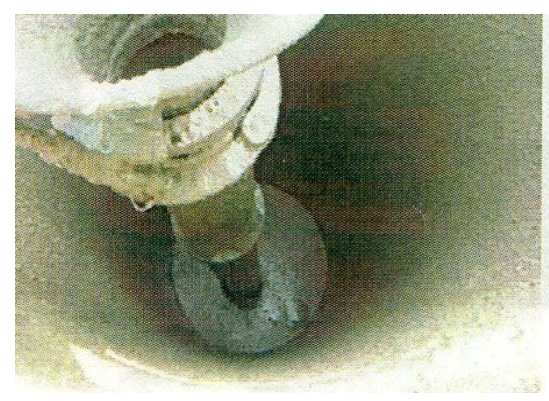

Figure 8: Pouring fluidization process soil using a tremie pipe.

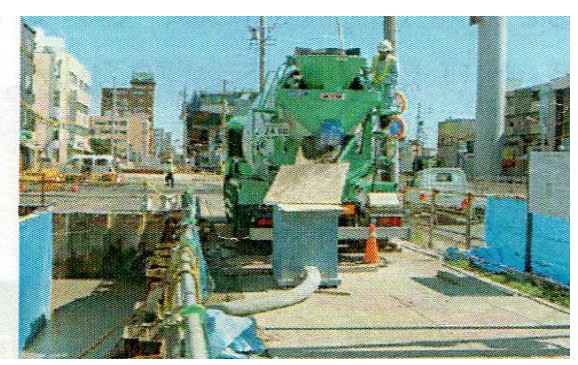

Figure 7: Pouring fluidization process soil using a notch tank.

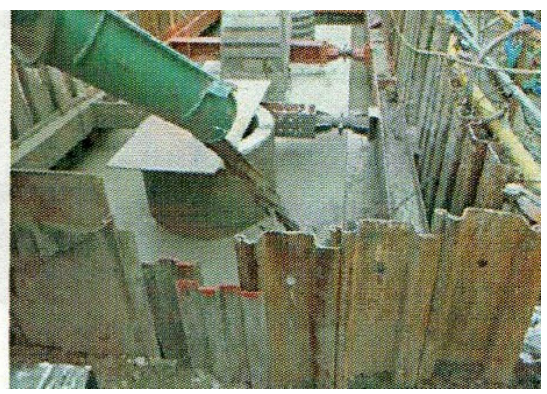

Figure 9: Pouring fluidization soil directly from the transit mixer.

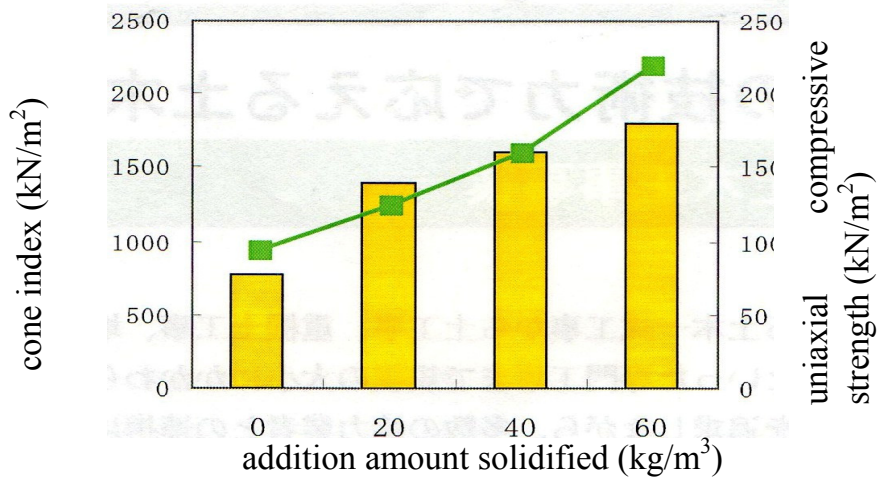

Figure 10: $\quad$ Test results of improved soil.

\section{Improved soil}

Improved soil by adding a modifier to recycled natural sand and cohesive soil separated out during the washing and classifying of construction sludge was 
produced. The improved soil can be reused by such improvement and recycling, where in the past, construction sludge has just been stabilized using quicklime. This improved soil can be made stable by using classified materials, having freedom in setting the blending ratio of the materials (sand and cohesive soil) through judicious choice of the type, quantity and strength of the additive and performing the improvement in the field. Figure 10 shows test results for the improved soil. The amount of additive when solidified $\left(\mathrm{kg} / \mathrm{m}^{3}\right)$ is shown on the horizontal axis, the cone index $\left(\mathrm{kN} / \mathrm{m}^{2}\right)$ is shown on the left vertical axis (bar graph) and the uniaxial compressive strength $\left(\mathrm{kN} / \mathrm{m}^{2}\right)$ is shown on the right vertical axis (line graph). Figures 11(a)-(d) are a flow chart for producing the improved soil.

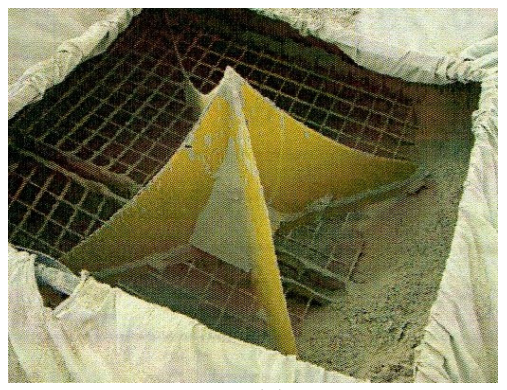

(a)

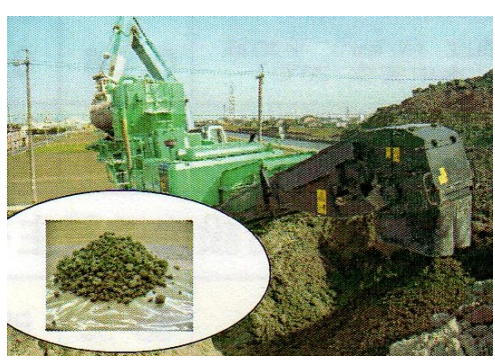

(c)

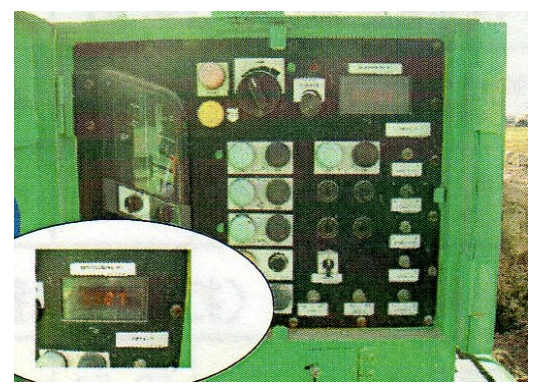

(b)

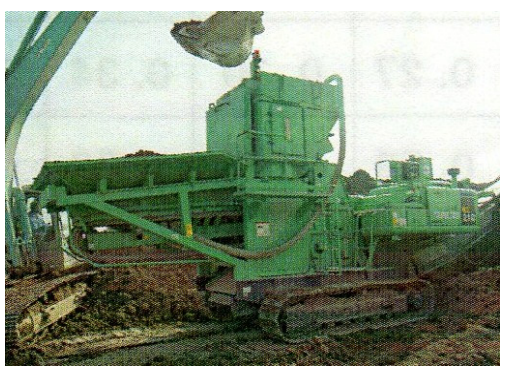

(d)

Figure 11: (a) The fixing agent (cement) is charged in a pit. (b) The volume of fixing agent added is set. (c) The raw soil is drawn. (b) The volume of fixing agent added is set.

\section{Conclusions}

In Japan, the "Law Concerning Recycling of Materials from Construction Work" was enacted in 2000. Enforcement began in 2002 [8]. How to reduce the final landfill disposal of construction sludge is a pressing matter because the residual capacity of final landfill sites is being exhausted. Very little construction sludge is recycled and illegal dumping is another serious problem. Given these conditions, the Japanese Ministry of Land, Infrastructure, and Transport published a guideline concerning the recycling of construction sludge in 
2006 [3]. Methods for dealing with the recycling of construction sludge were set forth in the "Law on Promoting Green Purchasing" of 2000 in a specific draft item concerning public works in 2010 [9]. Though many technologies for recycling construction sludge have been developed over the last 10 years, the rate of recycling has been struggling at about $70 \%$, small in comparison with the $100 \%$ recycling of concrete waste that has been achieved [2].

It will be important to establish technologies that create new products using construction sludge and to vigorously promote methods for its recycling.

\section{References}

[1] MITSUBISHI MATERIALS TECHNO, Construction Sludge Recycling Facility, https://www.mmc.co.jp/mmtec/english/020802.html, 2011.

[2] Construction sludge recycling association, Recycle of construction sludge, http://www.deido-recycling.jp/recycle/recycle $03 . \mathrm{htm}$

[3] Ministry of Land, Infrastructure and Transport, Guideline concerning on the recycle of construction sludge, http://www.mlit.go.jp/kisha06 /01/010612-html

[4] MURA CAM, Recycling projects, http://muracam.com/recycle.html

[5] Ministry of Environment, Environmental Standard concerned with soil pollution, http://www.env.go.jp/kijun/dojou.html

[6] Aichi Prefecture, AIKURU materials,http://www.pref.aichi.jp/kensetsukikaku/recycle/top/020gaiyou

[7] TAIHEIYOU CEMENT Co. Ltd, Report on cement tests, 2011.

[8] Ministry of Land, Infrastructure \& Transport, Law concerning Recycle of materials from Construction Work, http://www.env.go.jp/recycle/build /gaiyo.html

[9] Ministry of Environment, Law on Promoting Green Purchasing, http://www.env.go.jp/policy/hozen/green/g-law/index.html 